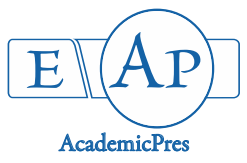

Oner F and Soysal AOS (2020)

Notulae Scientia Biologicae 12(3):693-701

DOI: $10.15835 / \mathrm{nsb} 12310766$

Research Article

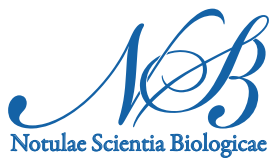

\title{
Determination of germination and seedling growth parameters of rice (Oryza sativa L.) varieties under stress conditions
}

\author{
Fatih ÖNER*, Ayşe Ö. Ş. SOYSAL \\ University of Ordu, Faculty of Agriculture, Department of Field Crops, Ordu, \\ Turkey; fatihoner38@gmail.com (*corresponding author); ayseozgesimsek@odu.edu.tr
}

\begin{abstract}
Rice (Oryza sativa L.) is an important food for more than half of the world's population. Globally, rice is grown on approximately 160 million hectares with an average annual production of 740.96 million tonnes. Salinity is an important abiotic factor for germination. In this study rice varieties were analysed for salt stress tolerance at germination growth stage. The response of eight rice varieties against six $(0,25,50,75,100,150$ $\mathrm{mM} \mathrm{NaCl}$ ) salinity levels were studied at germination stage. Seeds of eight rice varieties ('Yatkin', 'Miss-2013 Passali', 'Kale', 'Manyas Yildizi', 'Efe', 'Biga Incisi' and 'Osmancik-97') were kept under six salt stress levels. Number of seeds germinated (number), germination rate (\%), average germination time, fresh and dry weight of germinated seeds $(\mathrm{g})$, fresh and dry weight of the coleoptile $(\mathrm{g})$, fresh and dry weight of the radicle $(\mathrm{g})$, the length of the coleoptile and radicle $(\mathrm{mm})$ were recorded. The results showed that with increasing salt stress, germination in all the varieties was delayed. The increase in salt stress also reduced every measured trait significantly in all the varieties. Maximum germination percentage (100\%) was observed in 'Biga Incisi' under all the salt stress levels. Our research data would be helpful for identification of the tolerant varieties which can be studied further in terms of economically.
\end{abstract}

Keywords: abiotic stress; germination; $\mathrm{NaCl}$; rice; salinity stress seedling

\section{Introduction}

According to the data of the year of 2018, 782 million tonnes of paddy rice were produced in the world. In Turkey production has been made in the area of $120.137 \mathrm{ha}$ (FAO, 2020). So that; rice, one of the most important staple crops, feeds more than one half of the world's population.

Rice is among the most important cereal products consumed by people. Rice (Oryza) is a member of the family Poaceae. Oryza sativa is most commonly grown in Asia (Linares, 2002; Vaughan et al., 2008).

Salinity is one of the major obstacles in enhancing rice production in growing areas in the world. Salinity soluble salts which are washed in arid and semi-arid climates especially in arid and semi-arid climatic zones, escaping to the surface of the soil through capillary with high base water and accumulating on the surface of the soil by evaporation-ending water (Kwiatowski and King, 1998). Salinity's high levels reduce the ability of plants to absorb water from the soil and have toxic effects on cell metabolism (Munns and Tester, 2008). Rice is very sensitive to salinity stress (Anon, 2018). Salinity is an important abiotic stress factor that threatens the sustainability of world rice production. By adding salt at very low concentrations $(50 \mathrm{mM} \mathrm{NaCl})$ the yield 
can be reduced considerably, as is the case with many plants resistant to salt stress (Yeo and Flowers, 1986; Grattan et al., 2002; Munns and Tester, 2008). It has been shown by many researchers that salinity inhibits seed germination, pressure root and stem extension, reduces fresh weight and water content (Kabar and Baltepe 1987; Dash and Panda, 2001; El-Mashad and Kamel, 2001; Gulzar and Khan, 2002; Ashraf et al., 2002). Understanding the physiology of rice germination adaptation to under salinity will help to improve rice seedling concern under these adverse conditions (Kurniasih et al., 2013). The aim of this proposed study was to observe the effect of different salt doses on germination and germination properties of different rice varieties.

\section{Materials and Methods}

In this study, eight rice (Oryza sativa L.) varieties ('Yatkin', 'Miss-2013', 'Passali', 'Kale', 'Manyas Yildizi', 'Efe', 'Biga Incisi' and 'Osmancik-97') and 5 different salt ( $\mathrm{NaCl})$ concentrations (0, 25, 50, 100 and $150 \mathrm{ml})$ were used as materials. The research was carried out at the laboratory of Ordu University Faculty of Agriculture Department of Field Crops with 3 replications according to the factorial regulations in randomized parcels. In each Petri dish 20 seeds were planted for the study. These twenty seed per cultivar were placed on a filter paper in $10 \mathrm{~cm}$ petri dishes containing two sheets of filter paper were moistened initially with $5 \mathrm{ml}$ of distilled with different concentrates solutions $0,25,50,100$, and $150 \mathrm{ml} \mathrm{NaCl}$ (saline conditions). The petri dishes were placed in a growth chamber for 12 days at $25^{\circ} \mathrm{C} \pm 1$ for germination. In this research; number of seeds germinated (number), germination rate (\%), average germination time, fresh and dry weight of germinated seeds, fresh and dry weight of the coleoptile, fresh and dry weight of the radicle, the length of the coleoptile and radicle were calculated.

\section{Statistical analysis}

All obtained data were statistically analysed according to the SPSS 21 for the factorial regulations in randomized parcels. Duncan computer software package was used to test the differences between treatment means at $5 \%$ and $1 \%$ level of probability.

\section{Results and Discussion}

\section{Radicula and plumula length (mm)}

In this research, germination rate of eight rice varieties significantly decreased in increasing $\mathrm{NaCl}$ levels. All rice varieties showed more than $90 \%$ germination at all $\mathrm{NaCl}$ concentrations Figure 1 . Statistically nonsignificant were found in number of seeds germinated (number), the germination rate (\%). The percentage of germination significantly decreased in all varieties due to increasing salinity level indicated by Hakim et al. (2010). There was no difference between the varieties in terms of number of germination seeds (Table1). The average number of germinated seeds for the 8 varieties used was found to be 19.53 number. All the seeds in the 'Biga Incisi' variety were germinated (\%100) (Table1). A decrease in germination rate was observed after 50 $\mathrm{ml} \mathrm{NaCl}$ dosing. However, the germination rate was high even at $150 \mathrm{ml}$ of $\mathrm{NaCl}$. The highest GR's were 99.79, 98.54, 97.29 and $96.67 \%$ for $50,0,25$ and $100 \mathrm{ml} \mathrm{NaCl}$ salinity levels, respectively; the lowest GR (95.83\%) was determined at the highest salinity level $(150 \mathrm{ml} \mathrm{NaCl})$ (Figure 3). Hakim et al. (2010) reported in their research that salinity level reduced the osmotic effect so GR is reduced by this effect. There were statistically differences in mean germination time. The germination rates were calculated after 2 day in 0 and $25 \mathrm{NaCl}$ doses were the first in terms of day. At 0 and $25 \mathrm{NaCl}$ were the germination rate was calculated after 2 day). Ahmad and Wani (2014) reported the number of days were calculated of germination in the study after 4th day. Figures 1 and 2 show the values of germinated seeds (number), germination rate (\%), radicula and plumula length (mm). 
There was found a difference in length of coleoptile between cultivars, but no difference in radicle length. As a result of the statistical analysis, there was a statistically significant difference between salt concentrations in terms of coleoptile and radicula lengths. The length of coleoptile increased up to $100 \mathrm{ml}$ $\mathrm{NaCl}$. Whereas the length of the radicle decreased by salt levels. Cavusoğlu et al. (2007) also noted that increasing levels of saltiness have an inhibitory effect on seedling growth parameters (percent coleoptile, radicle and coleoptile extension, fresh weight) as well as the final germination percentage of barley seeds. Figures 1 and 2 shows also the values of coleoptile length and radicula length, average number of germinations, respectively. The longest coleoptile length was found $51.17 \mathrm{~cm}$ ('Osmancik-97') and the shortest length was found 33.33 cm ('Miss-2013'). The longest and shortest radicula value was found $59.45-49.41 \mathrm{~mm}$, 'Passali' and 'Biga Incisi' cultivars, respectively.

Table 1. Correlation table on average o number of seed germinated (number), germination rate (\%), average germination time (day), fresh and dry weight of coleoptile $(\mathrm{g})$, fresh and dry weight of the radicle (g) between each other and salinity concentrations $(\mathrm{NaCl})$

\begin{tabular}{|l|c|c|c|c|c|c|c|c|c|c|c|}
\hline & GP & $\begin{array}{c}\text { GR } \\
(\%)\end{array}$ & $\begin{array}{c}\text { AGT } \\
(\text { number })\end{array}$ & $\begin{array}{c}\text { FWGS } \\
(\mathrm{g})\end{array}$ & $\begin{array}{c}\text { DWGS( } \\
\mathrm{g})\end{array}$ & $\begin{array}{c}\text { FWC } \\
(\mathrm{g})\end{array}$ & $\begin{array}{c}\text { DWC } \\
(\mathrm{g})\end{array}$ & $\begin{array}{c}\text { FWR } \\
(\mathrm{g})\end{array}$ & $\begin{array}{c}\text { DWR } \\
(\mathrm{g})\end{array}$ & $\begin{array}{c}\text { CL } \\
(\mathrm{mm})\end{array}$ & $\begin{array}{c}\text { RL } \\
(\mathrm{mm})\end{array}$ \\
\hline GR & $1.00^{* *}$ & & & & & & & & & & \\
\hline AGT & -0.07 & -0.07 & & & & & & & & & \\
\hline FWGS & 0.11 & 0.11 & $-0.40^{* *}$ & & & & & & & & \\
\hline DWGS & 0.02 & 0.02 & $0.72^{* *}$ & $-0.41^{* *}$ & & & & & & & \\
\hline FWC & 0.12 & 0.12 & $-0.55^{* *}$ & $0.73^{* *}$ & $-0.43^{* *}$ & & & & & & \\
\hline DWC & 0.04 & 0.04 & $-0.38^{* *}$ & $0.35^{* *}$ & $-0.22^{*}$ & 0.49 & & & & & \\
\hline FWR & 0.007 & 0.00 & $-0.38^{* *}$ & $0.65^{* *}$ & $-0.50^{* *}$ & 0.51 & $0.21^{* *}$ & & & & \\
\hline DWR & 0.09 & 0.095 & $-0.32^{* *}$ & $0.44^{* *}$ & $-0.33^{* *}$ & 0.38 & $0.33^{* *}$ & $0.39^{* *}$ & & & \\
\hline $\mathrm{CL}$ & 0.14 & 0.149 & $-0.26^{* *}$ & 0.08 & -0.007 & 0.09 & $0.06^{* *}$ & -0.03 & -0.01 & & \\
\hline $\mathrm{RL}$ & 0.15 & 0.156 & $-0.49^{* *}$ & $0.53^{* *}$ & $-0.52^{* *}$ & 0.59 & $0.43^{* *}$ & $0.51^{* *}$ & $0.57^{* *}$ & 0.07 & \\
\hline $\mathrm{NaCl}$ doses & -0.16 & -0.16 & $0.63^{* *}$ & $-0.47^{* *}$ & $0.66^{* *}$ & -0.54 & $-0.36^{* *}$ & $-0.56^{* *}$ & $-.67^{* *}$ & -0.01 & -0.76 \\
\hline
\end{tabular}

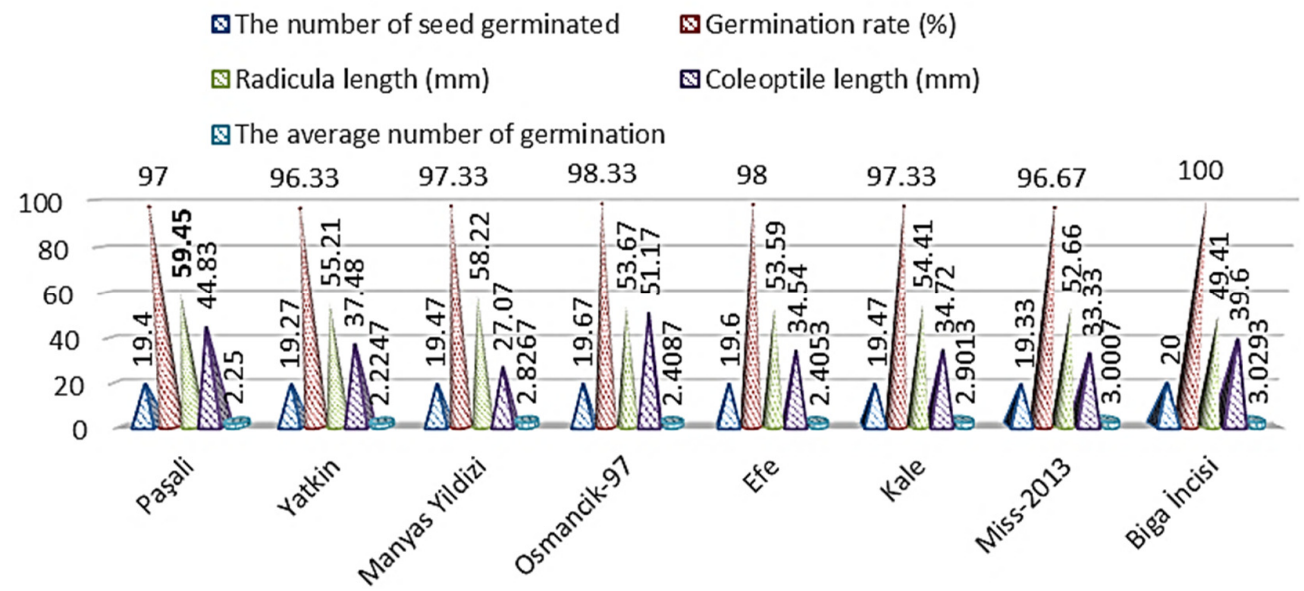

Figure 1. Different $\mathrm{NaCl}$ levels effect on the number of seed germinate (number), germinated rate (\%), coleoptile length and radicula length $(\mathrm{mm})$ and the average number of germination (number)

\section{Fresh and dry weight of coleoptile and radicula $(g)$}

Statistical analysis result was found significantly important for fresh and dry weight of the coleoptile. The longest fresh weight of coleoptile was found in 'Yatkin' cultivar. 'Manyas' 'Yildizi' and 'Kale' cultivars responded negatively to the increasing salt doses and the fresh weight of the coleoptile decreased. Except for these two varieties, the fresh weight of coleoptile increased till $50 \mathrm{ml} \mathrm{NaCl}$. After $50 \mathrm{ml}$ of NaCl , the values decreased (Figure 6). Similarly, Jamil and Rha (2007) observed that shoot length, root lengths and dry weight were decreased with increasing salt stress. When the dry weight of coleoptiles was compared with the control, 
they were increased with salinity except $150 \mathrm{ml} \mathrm{NaCl}$. Figure 6 shows that $150 \mathrm{ml} \mathrm{NaCl}$ was the limiting value. But the optimum dry weight was achieved at $50 \mathrm{~mL} \mathrm{NaCl}$ dose. Fresh and dry weight of the radicle were found statistically important. FWR and DWR decreased in different saline levels in all cultivars (Figure 7). Figure 7 shows that the highest FWR $(0.469 \mathrm{~g})$ and DWR $(0.0502 \mathrm{~g})$ and the lowest FWR and DWR, $0.1373 \mathrm{~g}, 0.022$ $\mathrm{g}$, respectively. In terms of this parameter, $25 \mathrm{ml} \mathrm{NaCl}$ values were in the same statistical group with the control group. The results conducted by Anbumalarmathi et al. (2013) research are similar to those we have found for radicula weight.

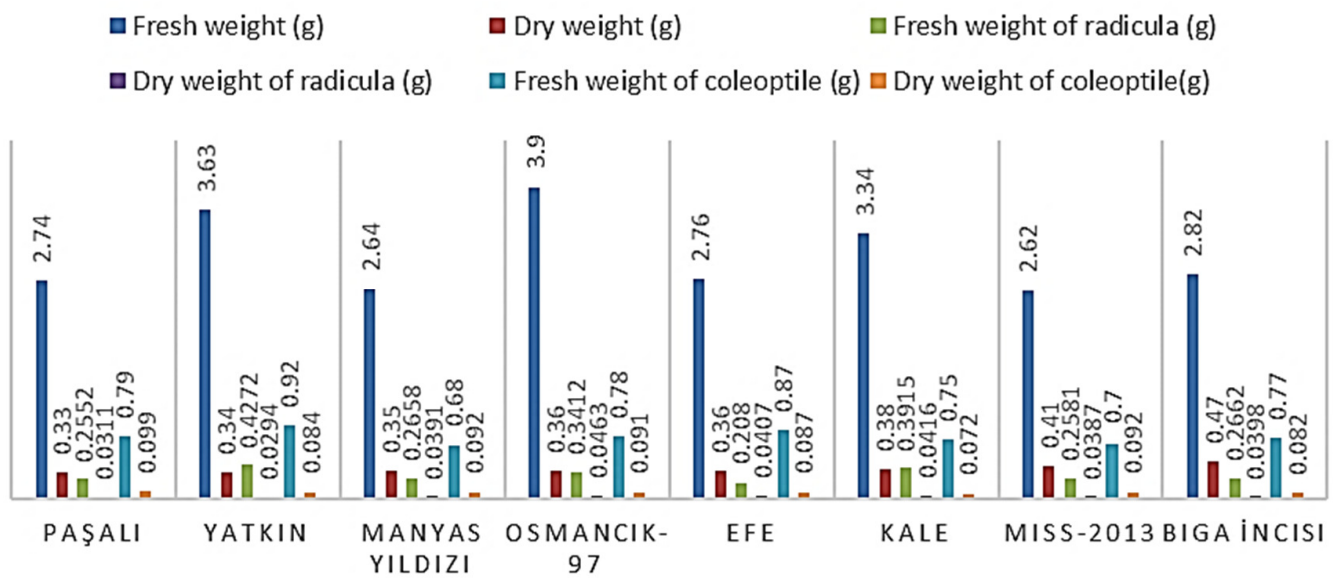

Figure 2. Different $\mathrm{NaCl}$ levels effect on fresh weight (g), dry weight $(\mathrm{g})$, dry weight of coleoptile (g), fresh weight of radicula $(\mathrm{g})$

Fresh and dry weight (g)

In our research, fresh and dry weight of germinated seeds effected by salinity. The seedling fresh weight was found directly proportional to the salinity levels (Figure 2). The fresh weight of germination diminished at all salt concentrations that were increased, the except of $25 \% \mathrm{NaCl}$ for 'Osmancik-97', 'Biga Incisi' and 'Pasteur'. There was a statistical difference in terms of dry weight of the seeds. Mean fresh weight of germination varied between 2.04 and 3.85. Afzal et al. (2012) reported that higher salinity affected negatively the FWGS (Fresh weight of germinated seed) reduced. Bohnert et al.(1995) and Al-Karaki (2001) said that; reduced fresh weight and water content of the fidelity in the salt environment can be explained by the lack of sufficient water intake of the roots due to the high osmotic pressure of the environment. Islam and Karim (2010) reported that in all genotype the seedling dry weight and percent relative dry weight were decreased due to increasing the salinity level.

The response of the dry weight of the seeds to increasing salt concentrations has been positive. This can be explained by the low water intake of the seeds as the salt rate increases. Ahmad and Wani (2014) have reported dry weight of the seeds were decreased by salinity levels. Their results are exactly the opposite of our results. The highest DWGS (Dry weight of germinated seed) $(0.44 \mathrm{~g})$ was determined at 150 , followed by 100 $\mathrm{ml} \mathrm{NaCl}$ with $0.41 \mathrm{~g}$ and $50 \mathrm{ml} \mathrm{NaCl}$ with $0.37 \mathrm{~g}$ in the different statistical group. And the lowest DWGS was determinate at $0 \mathrm{ml} \mathrm{NaCl}(0.31 \mathrm{~g})$. Anbumalarmathi et al. (2013) obtained that plumula dry weight showed inverse relationship with salt concentration. The highest FWGS was found $3.85 \mathrm{~g}$ at $25 \mathrm{ml} \mathrm{NaCl}$ and the lowest FWGS was found $2.04 \mathrm{~g}$ at the highest $\mathrm{NaCl}$ concentration $(150 \mathrm{ml}$ ) (Figure 5). 


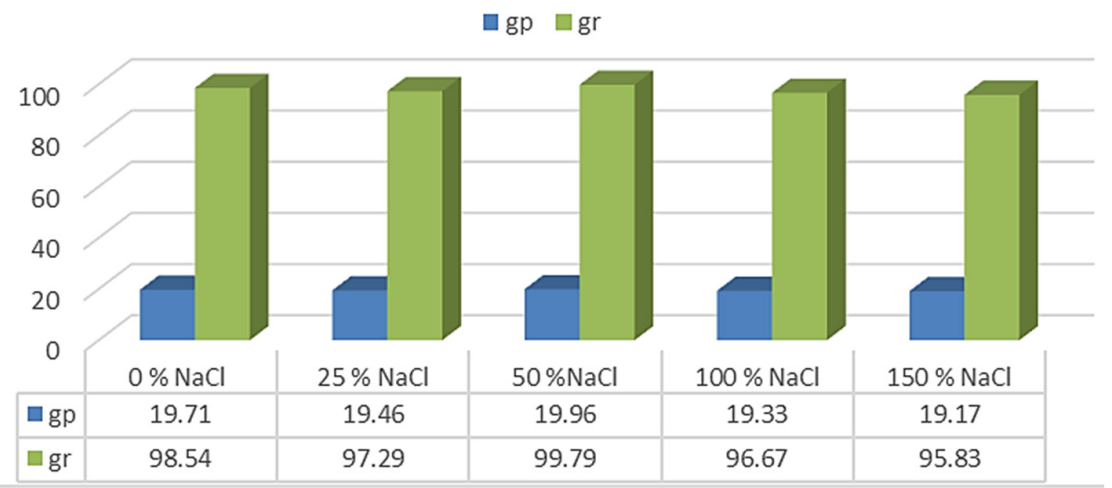

Figure 3. Effect of salt stress on germination percentage (GP) and germination rate (GR)

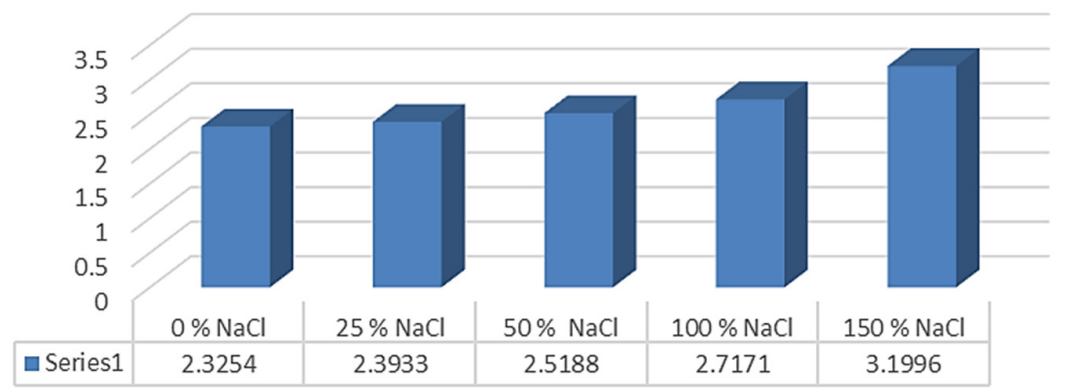

Figure 4. Effect of salt stress on average germination time (AGT)

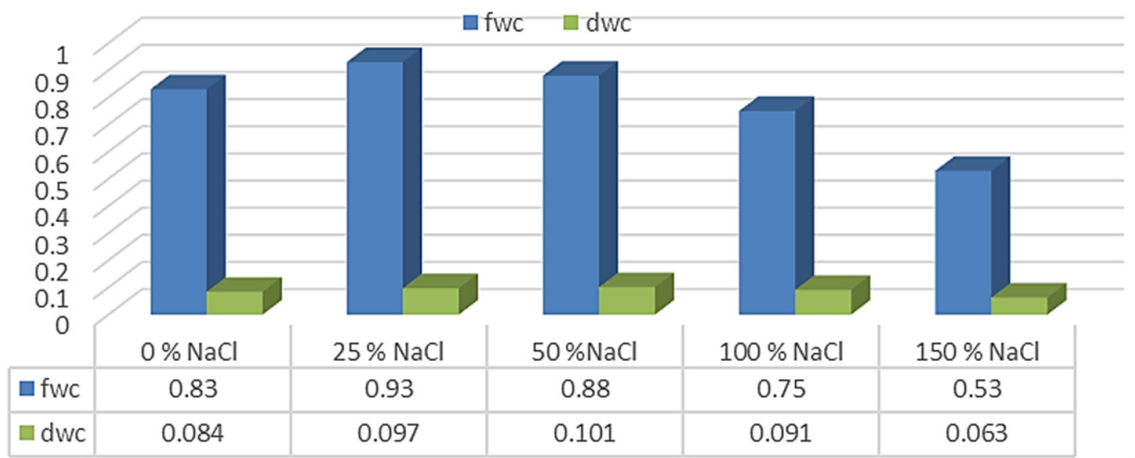

Figure 5. Effect of salt stress on fresh weight germinated seed (FWGS) and dry weight germinated seed (DWGS)

Almost all of the parameters regression results were found close to best value. Figure 8 show us the regression analysis table. Regression analysis table is show that our finding results are represent the truth.

When the correlation table (Table 1 ) is examined, there was a positive correlation between dry weight and average salt concentration of germinated seeds. There was a negative correlation between salt levels and fresh weight of germinated seeds, dry weight of the coleoptile, fresh and dry weight of the radicle.

The last table, variation table (Table 2), showed us $\mathrm{NaCl}$ and variety interaction found very important at $1 \%$ level $(\mathrm{P}<0.01)$ on average germination time, fresh and dry weight of coleoptile, fresh and dry weight of radicle, fresh weight and total seed weight. Interaction found significant $(\mathrm{P}<0.05)$ on seed weight, dry weight and coleoptile length. All rice varieties' impact was found statistically significant $(\mathrm{P}<0.01)$ on all of parameters except number of seed, germinated rate and radicle length. $\mathrm{NaCl}$ doses effects were found statistically important at $1 \%$ level $(\mathrm{P}<0.01)$ almost all parameters apart from number of seed, germinated rate and seed weight. And $\mathrm{NaCl}$ impact on coleoptile length at 5\% level (Table 2). 


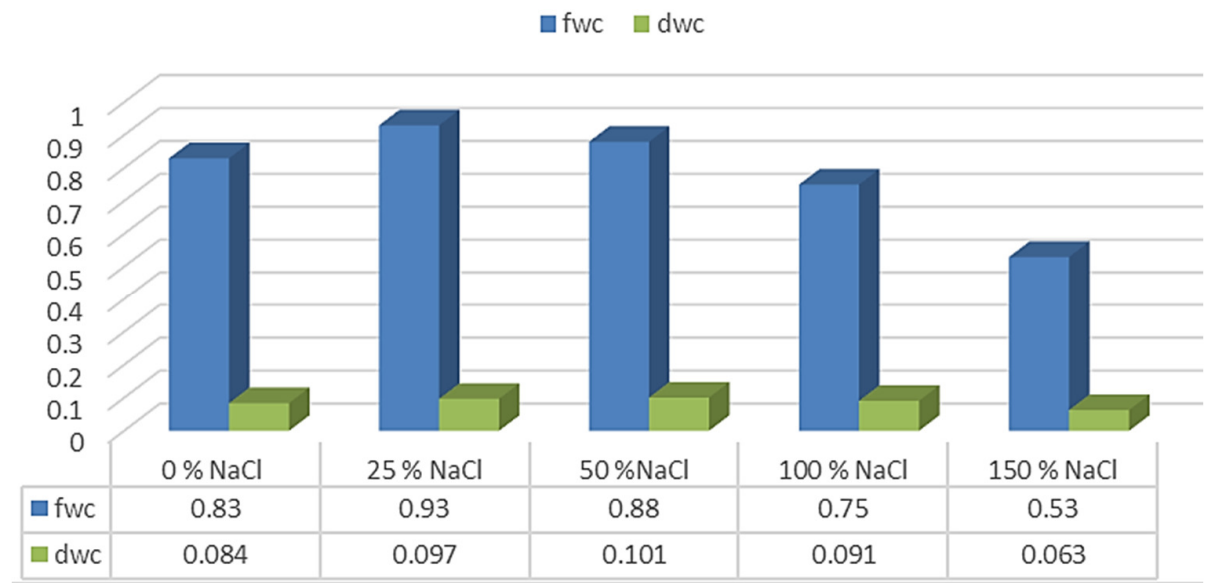

Figure 6. Effect of salt stress on fresh weight coleoptile (FWC) and dry weight coleoptile (DWC)

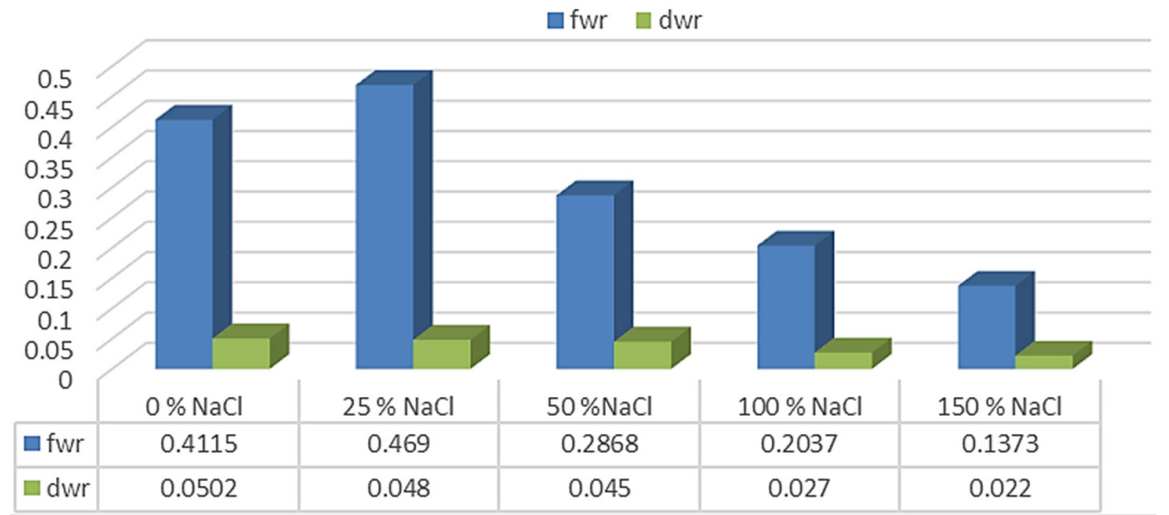

Figure 7. Effect of salt stress on fresh weight radicle (FWR) and dry weight radicle (DWR)

Table 2. Variation table on average o number of seed germinated (number), germination rate (\%), average germination time, fresh and dry weight of coleoptile $(\mathrm{g})$, fresh and dry weight of the radicle $(\mathrm{g})$ between each other and salinity concentrations $(\mathrm{NaCl})$

\begin{tabular}{|c|c|c|c|c|c|c|c|c|c|c|c|}
\hline & & \multicolumn{2}{|c|}{ NGS } & \multicolumn{2}{|c|}{ GR } & \multicolumn{2}{|c|}{ AGT } & \multicolumn{2}{|c|}{ SW } & & \\
\hline SOV & DF & $\mathrm{KO}$ & $\mathrm{F}$ & $\mathrm{KO}$ & $\mathrm{F}$ & $\mathrm{KO}$ & $\mathrm{F}$ & $\mathrm{KO}$ & $\mathrm{F}$ & & \\
\hline Variety & 7 & 0,808 & $0,561^{\mathrm{ns}}$ & 20,208 & $0,561^{\mathrm{ns}}$ & 1,751386 & $105,8826^{* *}$ & 0,123009 & $24,6484^{* *}$ & & \\
\hline $\mathrm{NaCl}$ & 4 & 2,346 & $1,627^{\mathrm{ns}}$ & 58,646 & $1,627^{\mathrm{ns}}$ & 2,958983 & $178,8896^{* *}$ & 0,007745 & $1,5520^{\mathrm{ns}}$ & & \\
\hline $\begin{array}{l}\mathrm{NaCl}^{*} \\
\text { Variety }\end{array}$ & 28 & 1,412 & $0,980^{\mathrm{ns}}$ & 35,31 & $0,980^{\mathrm{ns}}$ & 0,084929 & $5,1345^{* *}$ & 0,008469 & $1,6970^{*}$ & & \\
\hline Error & & 1,442 & & 36,042 & & 0,016541 & & 0,004991 & & & \\
\hline $\mathrm{CV}$ & & 0.0615 & & 0.0615 & & 0.0489 & & 0.1416 & & & \\
\hline & & \multicolumn{2}{|c|}{ FWC } & \multicolumn{2}{|c|}{ DWC } & \multicolumn{2}{|c|}{ FWR } & \multicolumn{2}{|c|}{ DWR } & & \\
\hline Variety & 7 & 0,092 & $4,641^{* *}$ & 0,001 & $10,736^{* *}$ & 0,087352 & $6,4256^{* *}$ & 0,000458 & $6,2707^{* *}$ & & \\
\hline $\mathrm{NaCl}$ & 4 & 0,603 & $30,448^{* *}$ & 0,005 & $59,606^{* *}$ & 0,461621 & $33,9567^{* *}$ & 0,004016 & $54,9408^{* *}$ & & \\
\hline $\begin{array}{l}\mathrm{NaCl}^{*} \\
\text { variety }\end{array}$ & 28 & 0,057 & $2,906^{* *}$ & 0,001 & $12,823^{* *}$ & 0,054695 & $4,0233^{* *}$ & 0,000322 & $4,4028^{* *}$ & & \\
\hline Error & & 0,020 & & $9,3.10^{-05}$ & & 0,063462 & & $7,31.10^{-15}$ & & & \\
\hline $\mathrm{CV}$ & & 0.1793 & & 1.1049 & & 0.3865 & & 0.2230 & & & \\
\hline & & \multicolumn{2}{|c|}{$\mathrm{FW}$} & \multicolumn{2}{|c|}{ DW } & \multicolumn{2}{|c|}{ TS } & \multicolumn{2}{|c|}{ RL } & \multicolumn{2}{|c|}{ CL } \\
\hline Variety & 7 & 3,722 & $4,866^{* *}$ & 0,029 & $45,999^{* *}$ & 0,042665 & $35,7238^{* *}$ & 148,9701 & $0,5812^{\mathrm{ns}}$ & 828,6604 & $5,2962^{* *}$ \\
\hline $\mathrm{NaCl}$ & 4 & 12,798 & $16,732^{* *}$ & 0,062 & $96,392^{* *}$ & 0,108327 & $90,7038^{* *}$ & 12480,42 & $48,6977^{* *}$ & 771,8715 & $4,9332^{*}$ \\
\hline $\begin{array}{l}\mathrm{NaCl}^{*} \\
\text { Variety } \\
\end{array}$ & 28 & 2,260 & $2,955^{* *}$ & 0,001 & $2,144^{*}$ & 0,00643 & $5,3836^{* *}$ & 390,0093 & $1,5218^{\mathrm{ns}}$ & 284,7421 & $1,8199^{*}$ \\
\hline Error & & 0,765 & & 0,001 & & 0,001194 & & 256,2836 & & 156,4636 & \\
\hline $\mathrm{CV}$ & & 0.2858 & & 0.0679 & & 0.0884 & & 0.02933 & & 0.3305 & \\
\hline
\end{tabular}

Significant level ${ }^{*} \mathrm{P}<0.05^{* *} \mathrm{P}<0.01$

SOV: Source Variation, NGS: Number of germinated seeds, GR: Germinated rate, AGT: Average germination time, SW: Seed weight, FWC: Fresh weight of coleoptile, DWC: Dry weight of coleoptile, FWR: Fresh weight of radicle, DWR: Dry weight of radicle, FW: Fresh weight, DW: Dry weight, TS: Total seed weight, RL: Radicle length, CL: Coleoptile length. 


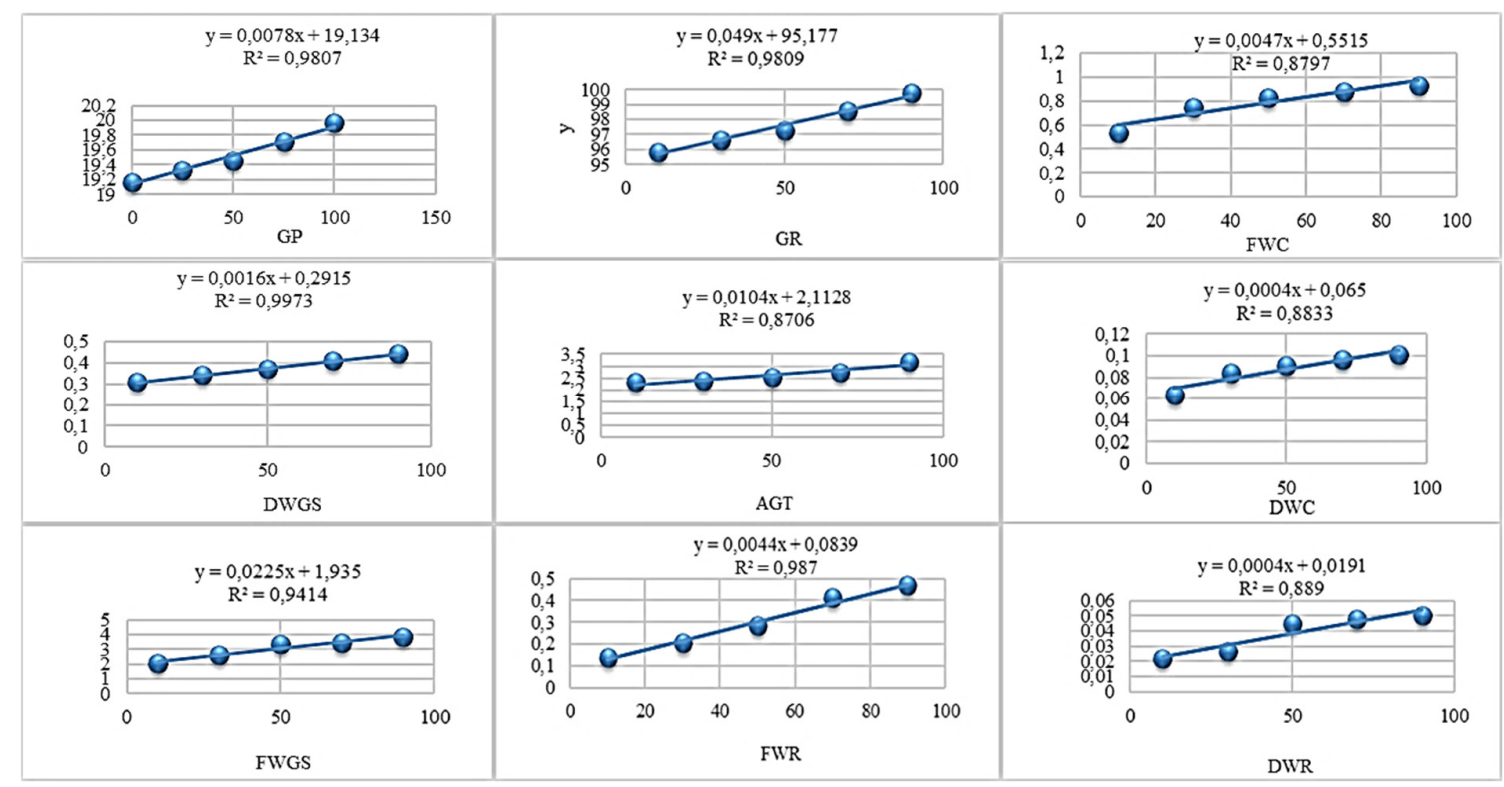

Figure 8. Regression analysis table on averages of number of seeds germinated (number), germination rate (\%), average germination time, fresh and dry weight of germinated seeds (g), fresh and dry weight of the coleoptile $(\mathrm{g})$, fresh and dry weight of the radicle $(\mathrm{g})$, the length of the coleoptile and radicle $(\mathrm{mm})$ between each other and salinity concentrations $(\mathrm{NaCl})$, effect of different salt stress percentage of fresh weight radicle (FWR) and dry weight radicle (DWR)

\section{Conclusions}

According the results obtained in the present investigation, we can conclude that overall showed better tolerance to salt stress with effect of $\mathrm{NaCl}$ on germination and biomass production at seedling stage. It is important to determine the yield and yield items of the varieties and to study for sustainability in saline areas especially where rice is grown. For this reason, like these researches should be increased in that's area.

\section{Authors' Contributions}

Both authors read and approved the final manuscript.

\section{Acknowledgements}

This research received no specific grant from any funding agency in the public, commercial, or not-forprofit sectors.

\section{Conflict of Interests}

The authors declare that there are no conflicts of interest related to this article. 


\section{References}

Afzal I, Hussain B, Basra SMA, Rehman H (2012). Priming with moringa leaf extract reduces imbibitional chilling injury in spring maize. Seed Science and Technology 40(2):271-276. https://doi.org/10.15258/sst.2012.40.2.13

Ahmad P, Wani R (2014). Biochemical and molecular approaches for drought tolerance in plants. In: Physiological Mechanisms and Adaptation Strategies in Plants Under Changing Environment, Springer, New York pp 1-29.

Al-Karaki GN (200)1. Germination, sodium, and potassium concentrations of barley seeds as influenced by salinity. Journal of Plant Nutrition 24(3):511-522. https://doi.org/10.1081/PLN-100104976

Anonymous (2018). Bibliography on salt tolerance, fibres, grains and special crops. United States Department of Agriculture. Retrieved 2018 November from https:/Www.ars.usda.gov/pacific-west-area/riversideca/agricultural-water-efficiency-and-salinity-research-unit/docs/databases/fgs-crops/

Anbumalarmathi J, Mehta P (2013). Effect of salt stress on germination of indica rice varieties. European Journal of Biological Sciences 6(1):1-6.

Ashraf M, Karim F, Rasul E (2002). Interactive effects of gibberellic acid (GA3) and salt stress on growth, ion accumulation and photosynthetic capacity of two spring wheat (Triticum aestivum L.) cultivars differing in salt tolerance. Plant Growth Regulation 36(1):49-59. https://doi.org/10.1023/A:1014780630479

Bohnert HJ, Nelson DE, Jensen RG (1995). Adaptations to environmental stresses. The Plant Cell 7(7):1099. https://doi.org/10.1105/tpc.7.7.1099

Çavuşoğlu K, Kılıç S, Kabar K (2007). Some morphological and anatomical observations during alleviation of salinity $(\mathrm{NaCI})$ stress on seed germination and seedling growth of barley by polyamines. Acta Physiologiae Plantarum 29(6):551-557.

Dash M, Panda SK (2001). Salt stress induced changes in growth and enzyme activities in germinating Phaseolus mungo seeds. Biologia Plantarum 44(4):587-589. https://doi.org/10.1023/A:1013750905746

El-Mashad AA, Kamel EA (2001). Amelioration of NaCl stress in Pisum sativum Linn. Indian Journal of Experimental Biology 39(5):469-475.

FAO (2020). Food and agriculture organization of the united nations. Retrieved 2020 August 05 from http://www.fao.org/faostat/en/\#data/QC

Grattan S, Zeng L, Shannon M, Roberts S (2002). Rice is more sensitive to salinity than previously thought. California Agriculture 56(6):189-198. https://doi.org/10.3733/ca.v056n06p189

Gulzar S, Khan MA (2002). Alleviation of salinity-induced dormancy in perennial grasses. Biologia Plantarum 45(4):617619. https://doi.org/10.1023/A:1022352012012

Hakim MA, Juraimi AS, Begum M, Hanafi MM, Ismail MR, Selamat A (2010). Effect of salt stress on germination and early seedling growth of rice (Oryza sativa L.). African Journal of Biotechnology 9(13):1911-1918. https://doi.org/10.5897/AJB09.1526

Islam MM, Karim MA (2010). Evaluation of rice (Oryza sativa L.) genotypes at germination and early seedling stage for their tolerance to salinity. The Agriculturists 8(2):57-65. https://doi.org/10.3329/agric.v8i2.7578

Jamil M, Rha ES (2007). Response of transgenic rice at germination and early seedling growth under salt stress. Pakistan Journal of Biological Sciences 10(23):4303-4306. https://doi.org/10.3923/pjbs.2007.4303.4306

Kabar K, Baltepe S (1987). Alleviation of salinity stress on germination of barley seeds by plant growth regulators. Doğa Turkish Journal of Biology 3:108-117.

Kurniasih B, Greenway H, Colmer TD (2013). Tolerance of submerged germinating rice to 50-200 $\mathrm{m} \mathrm{M} \mathrm{NaCl}$ in aerated solution. Physiologia Plantarum 149(2):222-233. https://doi.org/10.1111/ppl.12029

Kwiatkowski J, King CR (1998). Salinity mapping for resource management within the M.D. of Acadia, Alberta. Alberta Agriculture, Food and Rural Development, Edmonton.

Linares OF (2002). African rice (Oryza glaberrima): history and future potential. Proceedings of the National Academy of Sciences 99(25):16360-16365. https://doi.org/10.1073/pnas.252604599

Munns R, Tester M (2008). Mechanisms of salinity tolerance. Annual Review of Plant Biology 59:651-681. https://doi.org/10.1146/annurev.arplant.59.032607.092911

Vaughan DA, Lu BR, Tomooka N (2008). The evolving story of rice evolution. Plant Science 174(4):394-408. https://doi.org/10.1016/j.plantsci.2008.01.016

Yeo AR, Flowers TJ (1986). Salinity resistance in rice (Oryza sativa L.) and a pyramiding approach to breeding varieties for saline soils. Functional Plant Biology 13(1):161-173. http://dx.doi.org/10.1071/PP9860161 
OPEN ACCESS

(C) (9)

The journal offers free, immediate, and unrestricted access to peer-reviewed research and scholarly work. Users are allowed to read, download, copy, distribute, print, search, or link to the full texts of the articles, or use them for any other lawful purpose, without asking prior permission from the publisher or the author.

License - Articles published in Notulae Scientia Biologicae are Open-Access, distributed under the terms and conditions of the Creative Commons Attribution (CC BY 4.0) License.

(c) Articles by the authors; SHST, Cluj-Napoca, Romania. The journal allows the author(s) to hold the copyright/to retain publishing rights without restriction. 